\title{
Growth and Yield of Lettuce (Lactuca Sativa L.) Influenced As Nitrogen Fertilizer and Plant Spacing
}

\author{
M. R. $\operatorname{Hasan}^{1}$, A.K.M.M. Tahsin ${ }^{1}$, M. N. Islam ${ }^{2}$, M. A. Ali ${ }^{1}$ and J. Uddain ${ }^{1 *}$ \\ ${ }^{I}$ Department of Horticulture, Sher-e-Bangla Agricultural University, Bangladesh \\ ${ }^{2}$ Project officer, SEQAEP, DSHE, Ministry of education, Bangladesh
}

\begin{abstract}
The experiment was conducted in the Research Field of Sher-e-Bangla Agricultural University, Dhaka from October 2014 to February 2015.The present study was conducted to determine the optimum level of nitrogen fertilizer and proper plant spacing for better growth and yield of lettuce. The experiment consisted of two factors. Factor A: Nitrogen (4 levels) $N_{0}: 0$ (Control); $N_{1}: 50 ; N_{2}: 100$ and $N_{3}: 150 \mathrm{~kg} / \mathrm{ha}$ respectively; and Factor B: Plant spacing (3 levels), $S_{1}: 40 \mathrm{~cm} \times 20 \mathrm{~cm}, S_{2}: 40 \mathrm{~cm} \times 25 \mathrm{~cm} ; S_{3}: 40 \mathrm{~cm} \times 30 \mathrm{~cm}$. The Experiment was laid out in Randomized Complete Block Design (RCBD) with three replications. In case of nitrogen the highest yield ( $29.99 \mathrm{t} / \mathrm{ha}$ ) was recorded from $N_{3}$ and lowest $\left(18.65 \mathrm{t} / \mathrm{ha}\right.$ ) from $N_{0}$. In case of spacing the highest yield $\left(25.83 \mathrm{t} / \mathrm{ha}\right.$ ) was achieved from $S_{2}$ and lowest $\left(23.0 \mathrm{t} / \mathrm{ha}\right.$ ) from $S_{1}$. For interaction effect, the highest yield (31.31 t/ha) was obtained from $N_{3} S_{2}$ and lowest (16.79 t/ha) from $N_{0} S_{1}$. The highest BCR value (3.88) was recorded from $N_{3} S_{2}$ and lowest (2.1) from $N_{0} S_{1}$. So, $150 \mathrm{~kg} / \mathrm{ha}$ urea with spacing of $40 \mathrm{~cm} \times 25 \mathrm{~cm}$ were best for growth and yield of lettuce.
\end{abstract}

Key Words: Nitrogen, Spacing, Growth, Yield, Lettuce

\section{Introduction}

Lettuce (Lactuca sativa L.) an annual leafy herb belongs to the family Compositae is one of the most popular salad crops and occupies the largest production area among salad crops in the world. It is popular for its delicate, crispy texture and slightly bitter taste with milky juice as fresh condition. It is the most popular amongst the salad vegetable crops (Squire et al., 1987). Lettuce is rich in vitamin A and minerals like calcium and iron. It is usually used as salad with tomato, carrot, cucumber or other salad vegetable and often served alone or with dressing.

Lettuce is getting popularity day by day but its production package is not much known to the Bangladeshi farmers. This vegetable requires a high rate of nitrogen for growth and development. In Iran, farmers who applied excesses nitrogen fertilizer to increase crop yield disturbed the equilibrium balance of nutrient elements in the soil, caused pollution, decreased crop quality and thus a great part of the nation's resources became useless (Tehrani and Malakouti, 1997). Adequate $\mathrm{N}$ levels are also associated with "sizing," solid heads, and earliness of maturity in lettuce. Lettuce with $\mathrm{N}$ deficiency appears lighter green.

Plant spacing for lettuce cultivation is an important criterion for attaining maximum vegetative growth and an important aspect of crop production for maximizing the yield. Optimum plant spacing ensures judicious use of natural resources and makes the intercultural operations easier. It helps to increase the number of leaves, branches and healthy foliage. Densely planted crop obstruct the proper growth and development. On the other hand, wider spacing ensures the basic nutritional requirements but decrease the total number of plants as well as total yield. Yield may be increased for any crop up to $25 \%$ by using optimum spacing in leafy vegetable (Bansal, et al., 1995). Considering the above factors, the present study was undertaken to find out the suitable combination of nitrogen and plant spacing for ensuring the higher yield of lettuce.

\section{Materials And Methods}

The present experiment was carried out in the farm of Sher-e-Bangla Agricultural University, Sher-eBangla Nagar, Dhaka, Bangladesh. The location of the experimental site is $23^{0} 74^{\prime} \mathrm{N}$ latitude and $90^{0} 35^{\prime} \mathrm{E}$ longitude and at an elevation of $8.2 \mathrm{~m}$ from sea level (Anon., 1989). Seeds of lettuce cultivar, 'Grand Raphids' were used in the experiment. The experiment was laid out in Randomized Complete Block Design with three replications. The experiment consisted of two factors such as factor A: Nitrogen levels, $\mathrm{N}_{0}: 0 \mathrm{~kg} / \mathrm{ha}$ (Control), $\mathrm{N}_{1}: 50 \mathrm{~kg} / \mathrm{ha}, \mathrm{N}_{2}: 100 \mathrm{~kg} / \mathrm{ha}, \mathrm{N}_{3}: 150 \mathrm{~kg} / \mathrm{ha}$ and factor B: Plant spacing, $\mathrm{S}_{1}: 40 \mathrm{~cm} \times 20 \mathrm{~cm}, \mathrm{~S}_{2}: 40 \mathrm{~cm} \times 25 \mathrm{~cm}$ and $\mathrm{S}_{3}: 40 \mathrm{~cm} \times 30 \mathrm{~cm}$. There were 12 treatment combinations such as $\mathrm{N}_{0} \mathrm{~S}_{1}, \mathrm{~N}_{0} \mathrm{~S}_{2}, \mathrm{~N}_{0} \mathrm{~S}_{3}, \mathrm{~N}_{1} \mathrm{~S}_{1}, \mathrm{~N}_{1} \mathrm{~S}_{2}, \mathrm{~N}_{1} \mathrm{~S}_{3}$, $\mathrm{N}_{2} \mathrm{~S}_{1}, \mathrm{~N}_{2} \mathrm{~S}_{2}, \mathrm{~N}_{2} \mathrm{~S}_{3}, \mathrm{~N}_{3} \mathrm{~S}_{1}, \mathrm{~N}_{3} \mathrm{~S}_{2}$ and $\mathrm{N}_{3} \mathrm{~S}_{3}$. There were 36 unit plots and the size of the each unit plot was $3.0 \mathrm{~m} \times$ $1.6 \mathrm{~m}$. The distance maintained between two blocks and two plots were $1.0 \mathrm{~m}$ and $0.5 \mathrm{~m}$, respectively.

*Corresponding author:

DrJasim Uddain, Department of Horticulture,Sher-e-Bangla Agricultural University,Dhaka-1207, Bangladesh. E-mail: Uddain.jasim@gmail.com/jasimhort@sau.edu.bd 
The data obtained for different parameters were statistically analyzed to find out the significance difference of nitrogen fertilization and plant spacing on yield and yield contributing characters of lettuce. The mean values of all the characters were calculated and analysis of variance was performed by the ' $F$ ' (variance ratio) test. The significance of the difference among the treatment combinations means was estimated by the Duncan's Multiple Range Test (DMRT) at 5\% level of probability (Gomez and Gomez, 1984).

\section{1. Plant height}

\section{Results And Discussion}

Plant height of lettuce did not varied significantly between $\mathrm{N}_{1}, \mathrm{~N}_{2}$ and $\mathrm{N}_{3}$ level of nitrogen. But plant height varied significantly at 30, 40,50 and 60 DAT (Table 1). At all the growth stages, the tallest plant (16.94, $21.85,26.36$ and $30.0 \mathrm{~cm}$ at $30,40,50$ and 60 DAT respectively) was recorded from $\mathrm{N}_{3}(150 \mathrm{~kg} \mathrm{~N} / \mathrm{ha})$ which was statistically similar $(21.3 \mathrm{~cm})$ to $\mathrm{N}_{2}(100 \mathrm{~kg} \mathrm{~N} / \mathrm{ha})$ at $40 \mathrm{DAT}$. Again, the shortest plant $(10.36,13.7,18.42$ and $21.89 \mathrm{~cm}$ at 30, 40, 50 and 60 DAT respectively) was observed from $\mathrm{N}_{0}(0 \mathrm{~kg} \mathrm{~N} / \mathrm{ha})$. It was revealed that with the higher doses of nitrogen level, increase plant height was observed, where no nitrogen application showed lowest plant height at all growth stages. Nitrogen fertilizer ensured favorable condition for the elongation of lettuce plant with optimum vegetative growth and the ultimate results was the tallest plant. Similar results were observed by Tittonellet al. (2003), Rincon et al. (1998) and Boroujerdnia and Ansari (2007).

Statistically significant variation on plant height of lettuce was shown due to different plant spacing at 30,40, 50 and 60 DAT (Table 1). At different days after transplanting (DAT) the tallest plant (16.73, 22.2, 26.55 and $30.46 \mathrm{~cm}$ at 30, 40, 50 and 60 DAT respectively) was recorded from $\mathrm{S}_{1}(40 \mathrm{~cm} \times 20 \mathrm{~cm})$. On the other hand, the shortest plant (13.3, 16.71, 21.0 and $24.21 \mathrm{~cm}$ at $30,40,50$ and 60 DAT respectively) was found from $\mathrm{S}_{3}(40$ $\mathrm{cm} \times 30 \mathrm{~cm}$ ). Results under the present experiment showed that closer spacing showed higher plant height where higher plant spacing showed lower plant height because of closer spacing plant compete for light which helps to elongate plant than the wider spacing. Moniruzzaman (2006) reported similar findings from the closest spacing.

Significant variation was observed due to interaction effect of nitrogen and plant spacing in terms of plant height of lettuce at 30, 40, 50 and 60 DAT (Table 1). The tallest plant $(20.0,26.21,31.89$ and $35.01 \mathrm{~cm}$ at $30,40,50$ and 60 DAT, respectively) was recorded from $\mathrm{N}_{3} \mathrm{~S}_{1}$. The combination of $\mathrm{N}_{2} \mathrm{~S}_{1}$ also showed higher plant height but significantly different from $\mathrm{N}_{3} \mathrm{~S}_{1}$. The shortest plant $(9.71,11.89,17.54$ and $20.11 \mathrm{~cm}$ at 30,40 and 50 DAT, respectively) was found from $\mathrm{N}_{0} \mathrm{~S}_{3} \mathrm{~N}_{0} \mathrm{~S}_{2}$ which also showed lower plant height but significantly different from $\mathrm{N}_{0} \mathrm{~S}_{3}$.

\section{Table 1}

\subsection{Number of leaves/plant}

Significant variation was recorded for number of leaves/plant of lettuce with application of different levels of nitrogen at 30, 40, 50 and 60 DAT (Table 2). At 30, 40, 50 and 60 DAT the maximum number of leaves/plant was 17.45, 24.85, 29.25 and 27.2 respectively which was obtained from $\mathrm{N}_{3}(150 \mathrm{~kg} \mathrm{~N} / \mathrm{ha})$ and the minimum number of leaves/plant (12.65, 17.23, 22.7 and 21.45 at 30, 40, 50 and 60 DAT respectively) was found from $\mathrm{N}_{0}(0 \mathrm{~kg} \mathrm{~N} / \mathrm{ha})$. It was revealed that the higher doses of nitrogen level showed higher number of leaves/plant where no nitrogen application showed the lowest at all growth stages. Maximum number of leaves/plant was recorded for highest level of nitrogen because nitrogenous fertilizer ensures favorable condition for the growth of lettuce. Similar findings were observed by Tittonellet al. (2003), Rincon et al. (1998) and Boroujerdnia and Ansari (2007).

No significant variation was found for number of leaves per plant between $S_{2}$ and $S_{3}$. But Due to different plant spacing, statistically significant variation was recorded for number of leaves per plant of lettuce at 30, 40, 50 and 60 DAT (Table 2). At different days after transplanting (DAT) the maximum number of leaves per plant $\left(16.37,23.14,27.39\right.$ and 25.6 at $30,40,50$ and 60 DAT respectively) was obtained from $\mathrm{S}_{2}(40 \mathrm{~cm} \times$ $25 \mathrm{~cm})$ which was closely followed by $\mathrm{S}_{3}(40 \mathrm{~cm} \times 30 \mathrm{~cm})$. At the same condition, the minimum number of leaves/plant (14.0, 19.68, 24.31 and 22.68 at 30, 40, 50 and 60 DAT respectively) was recorded from $S_{1}(40 \mathrm{~cm}$ $\times 20 \mathrm{~cm}$ ). It was revealed that with the increases of spacing, number of leaves per plant also increased. Enough space for vertical and horizontal expansion in the optimum spacing that leads for production of maximum number of leaves per plant than the closer spacing. Steingrobe and Schenk (1994) also reported similar results earlier. Interaction effect of nitrogen and plant spacing showed significant difference among the treatments in terms of number of leaves per plant of lettuce at 30,40,50 and 60 DAT (Table 2). The maximum number of leaves/plant (19.16, 27.1, 31.77 and 29.71 at 30, 40, 50 and 60 DAT, respectively) was found from $\mathrm{N}_{3} \mathrm{~S}_{2}$. The treatment combination of $\mathrm{N}_{3} \mathrm{~S}_{3}$ also showed higher number of leaves/plant but significantly different from $\mathrm{N}_{3} \mathrm{~S}_{2}$. Again, the minimum number of leaves/plant $(11.54,15.44,21.34$ and 20.51 at 30, 40, 50 and 60 DAT respectively) was attained from $\mathrm{P}_{0} \mathrm{~S}_{1}$. It was revealed that optimum level of nitrogen and plant spacing ensured maximum number of leaves/plant. 


\section{Table 2}

\subsection{Leaf length}

Application of different levels of nitrogen showed statistically significant variation for leaf length of lettuce at different days after transplanting (Table 3). At 30, 40, 50 and 60 DAT the highest leaf length was $13.0,18.0,22.41$ and $25.28 \mathrm{~cm}$ respectively which was achieved from $\mathrm{N}_{3}(150 \mathrm{~kg} \mathrm{~N} / \mathrm{ha})$. Again, the lowest leaf length $\left(9.43,10.63,16.76\right.$ and $17.73 \mathrm{~cm}$ at $30,40,50$ and 60 DAT respectively) was found from $\mathrm{N}_{0}(0 \mathrm{~kg} \mathrm{~N} / \mathrm{ha})$. Results showed that higher doses of nitrogen cause higher leaf length. Optimum vegetative growth was occurred due to higher amount of nitrogen fertilizer that leads for the growth of lettuce and the ultimate results was the longest leaf. The results obtained earlier by Boroujerdnia and Ansari (2007) was similar with the present study.

Leaf length of lettuce was not significantly varied between $S_{2}$ and $S_{3}$. But leaf length was significantly influenced due to different plant spacing at 30, 40, 50 and 60 DAT (Table 3). The highest leaf length (12.44, $16.44,21.13$ and $23.67 \mathrm{~cm}$ at 30, 40, 50 and 60 DAT respectively) was observed from $\mathrm{S}_{3}(40 \mathrm{~cm} \times 30 \mathrm{~cm})$ which was statistically identical with $S_{2}(40 \mathrm{~cm} \times 25 \mathrm{~cm})$ and the lowest leaf length $(10.51,12.88,18.64$ and $20.66 \mathrm{~cm})$ was recorded from $S_{1}(40 \mathrm{~cm} \times 20 \mathrm{~cm})$. It was revealed that with the increases of spacing leaf length showed increasing trend. In case of closer spacing plant compete for light and with the time being leaf length decreases. Sodkowski and Rekowska (2003) reported longest leaf from closer spacing.

Statistically significant variation was recorded due to interaction effect of nitrogen and plant spacing in terms of leaf length of lettuce at 30, 40, 50 and 60 DAT (Table 3). The highest leaf length $(13.89,19.89,23.79$ and $27.00 \mathrm{~cm}$ at 30, 40, 50 and 60 DAT respectively) was found from $\mathrm{N}_{3} \mathrm{~S}_{2}$. The similar result was also observed with $\mathrm{N}_{3} \mathrm{~S}_{3}$ at 40 and 60 DAT. The lowest leaf length $(8.94,9.0,15.19$ and $16.0 \mathrm{~cm}$ at 30, 40, 50 and 60 DAT respectively) was obtained from $\mathrm{N}_{0} \mathrm{~S}_{1}$. The treatment combination of $\mathrm{N}_{0} \mathrm{~S}_{2}$ also showed lower leaf length but significantly different from $\mathrm{N}_{3} \mathrm{~S}_{2}$ at 40,50 and 60 DAT. Data revealed that optimum level of nitrogen and plant spacing ensured the highest leaf length with maximum vegetative growth.

\section{Table 3}

\subsection{Leaf breadth}

Application of different levels of nitrogen showed statistically significant variation for leaf breadth of lettuce at different days after transplanting (Table 4). At 30, 40,50 and 60 DAT, the highest leaf breadth was $11.33,15.58,23.26$ and $26.57 \mathrm{~cm}$, respectively which was achieved from $\mathrm{N}_{3}(150 \mathrm{~kg} \mathrm{~N} / \mathrm{ha})$. Again, the lowest leaf breadth $\left(6.7,9.63,12.72\right.$ and $15.73 \mathrm{~cm}$ at $30,40,50$ and 60 DAT respectively) was found from $\mathrm{N}_{0}(0 \mathrm{~kg}$ $\mathrm{N} / \mathrm{ha}$ ). Results showed that higher doses of nitrogen cause higher leaf breadth. Optimum vegetative growth was occurred due to higher amount of nitrogen fertilizer that leads for the growth of lettuce and the ultimate results was the widest leaf. The results obtained earlier by Boroujerdnia and Ansari (2007) was similar with the present study.

Leaf breadth of lettuce was not significantly varied between $S_{2}$ and $S_{3}$. But leaf breadth was significantly influenced due to different plant spacing at 30, 40,50 and 60 DAT (Table 4). The highest leaf breadth $\left(10.45,14.62,21.18\right.$ and $24.69 \mathrm{~cm}$ at $30,40,50$ and 60 DAT respectively) was observed from $\mathrm{S}_{3}(40 \mathrm{~cm}$ $\times 30 \mathrm{~cm})$ and the lowest leaf breadth $(8.0,11.54,16.27$ and $19.2 \mathrm{~cm})$ was recorded from $\mathrm{S}_{1}(40 \mathrm{~cm} \times 20 \mathrm{~cm})$. It was revealed that with the increases of spacing leaf breadth showed increasing trend. In case of closer spacing plant compete for light and with the time being leaf breadth decreases.

Statistically significant variation was recorded due to interaction effect of nitrogen and plant spacing in terms of leaf breadth of lettuce at different growth stages (Table 4). The highest leaf breadth $(12.4,16.99,25.0$ and $28.61 \mathrm{~cm}$ at 30, 40, 50 and 60 DAT respectively) was found from $\mathrm{N}_{3} \mathrm{~S}_{3}$ which was statistically identical with $\mathrm{N}_{3} \mathrm{~S}_{3}$ at 30,40 and 60 DAT. The lowest leaf breadth $(6.1,8.0,11.49$ and $14.25 \mathrm{~cm}$ at 30, 40, 50 and 60 DAT respectively) was obtained from $\mathrm{N}_{0} \mathrm{~S}_{1}$. The combination of $\mathrm{N}_{0} \mathrm{~S}_{2}$ and $\mathrm{N}_{0} \mathrm{~S}_{3}$ also showed lower leaf breadth but significantly different from $\mathrm{N}_{3} \mathrm{~S}_{3}$ at 40,50 and 60 DAT. Data revealed that optimum level of nitrogen and plant spacing ensured the highest leaf breadth with maximum vegetative growth.

\section{Table 4}

\subsection{Fresh weight/plant}

Lettuce fresh weight/plant showed statistically significant variation due to the application of different levels of nitrogen at different days after transplanting (Table 5). At 30, 40, 50 and 60 DAT the maximum fresh weight/plant $\left(87.23,102.3,115.3\right.$ and $126.0 \mathrm{~g}$ respectively) was obtained from $\mathrm{N}_{3}(150 \mathrm{~kg} \mathrm{~N} / \mathrm{ha})$ which was significantly different from all other treatments. On the other hand, the minimum fresh weight/plant (45.0, 56.12, 67.73 and $75.79 \mathrm{~g}$ at 30, 40, 50 and 60 DAT respectively) was found from $\mathrm{N}_{0}(0 \mathrm{~kg} \mathrm{~N} / \mathrm{ha})$. It was revealed that with the increase of nitrogen application, fresh weight/plant increase due to optimum vegetative growth. Nitrogen fertilizer ensures favorable condition for the growth of lettuce with optimum vegetative growth and the ultimate results was the highest fresh weight/plant. The results obtained earlier by Tittonellet al. 
(2003), Rincon et al. (1998) and Boroujerdnia and Ansari (2007) were similar with the present study. Fresh weight/plant of lettuce showed statistically significant variation due to different plant spacing at different growth stages (Table 5). At 30, 40, 50 and 60 DAT, the maximum fresh weight of plant $(81.55,94.58,109.0$ and $117.0 \mathrm{~g}$ at $30,40,50$ and 60 DAT, respectively) was observed from $S_{3}(40 \mathrm{~cm} \times 30 \mathrm{~cm})$ while the minimum fresh weight/plant was 55.0, 65.4, 75.36 and $83.0 \mathrm{~g}$ respectively) was found from $\mathrm{S}_{1}(40 \mathrm{~cm} \times 20 \mathrm{~cm})$. It was revealed that with the increases of spacing fresh weight of plant showed increasing trend. In case of wider spacing plant receive enough light and nutrients which leads to attain maximum fresh weight of plant. Similar result was also observed by Sharma et al. (2001). Interaction effect of different levels of nitrogen application and plant spacing showed statistically significant variation for fresh weight of lettuce plant at different growth stages (Table 5). The maximum fresh weight/plant (104.1, 120.1, 136.2 and $144.9 \mathrm{~g}$ at 30, 40, 50 and 60 DAT respectively) was found from $\mathrm{N}_{3} \mathrm{~S}_{3}$ where the minimum fresh weight/plant $(36.65,44.69,54.44$ and $62.59 \mathrm{~g})$ was with $\mathrm{N}_{0} \mathrm{~S}_{1}$. It was revealed that optimum level of nitrogen and plant spacing ensured maximum vegetative growth that ensured highest fresh weight/ plant.

\section{Table 5}

\subsection{Dry weight/plant}

Lettuce dry weight/plant showed statistically significant variation due to the application of different levels of nitrogen at different growth stages (Table 6). At 30, 40, 50 and 60 DAT, the maximum dry weight/plant $\left(12.46,14.68,16.56\right.$ and $18.0 \mathrm{~g}$, respectively) was obtained from $\mathrm{N}_{3}(150 \mathrm{~kg} \mathrm{~N} / \mathrm{ha})$ which was significantly different from all other treatments. On the other hand, the minimum dry weight/plant $(6.8,8.23$, 9.83 and $10.89 \mathrm{~g}$ at $30,40,50$ and 60 DAT respectively) was found from $\mathrm{N}_{0}(0 \mathrm{~kg} \mathrm{~N} / \mathrm{ha})$. It was revealed that with the increase of nitrogen application, dry weight/plant increase due to more availability of nutrients among the plants during vegetative growth. Similar results were also obtained by Tittonellet al. (2003) and MahmoudiKliber (2005). Dry weight/plant of lettuce showed statistically significant variation due to different plant spacing at different growth stages (Table 6). At 30, 40, 50 and 60 DAT, the maximum dry weight/plant $\left(11.83,13.72,15.67\right.$ and $16.81 \mathrm{~g}$ at $30,40,50$ and 60 DAT respectively) was observed from $\mathrm{S}_{3}(40 \mathrm{~cm} \times 30 \mathrm{~cm})$ while the minimum dry weight/plant was $8.0,9.36,10.84$ and $10.89 \mathrm{~g}$ respectively was found from $S_{1}(40 \mathrm{~cm} \times$ $20 \mathrm{~cm}$ ). It was revealed that with the increases of spacing dry weight of plant showed increasing trend because of less competition for nutrients among the plants during growth stages. Similar result was also tested by Sharma et al. (2001). Interaction effect of different levels of nitrogen application and plant spacing showed statistically significant variation for dry weight of lettuce plant at different growth stages (Table 6). The maximum dry weight/plant $(14.94,17.29,19.56$ and $20.8 \mathrm{~g}$ at 30, 40, 50 and 60 DAT, respectively) was found from $\mathrm{N}_{3} \mathrm{~S}_{3}$ where the minimum dry weight/plant $(5.84,6.85,7.76$ and $8.99 \mathrm{~g})$ was with $\mathrm{N}_{0} \mathrm{~S}_{1}$. It was revealed that optimum level of nitrogen and plant spacing ensured maximum vegetative growth that ensured highest dry weight/plant.

\section{Table 6}

\subsection{Yield/ha}

Different levels of nitrogen application influenced yield/ha significantly at different growth stages of lettuce (Table 7). At 30, 40, 50 and $60 \mathrm{DAT}$, the highest yield/ha was 6.0, 7.15, 8.0 and $8.76 \mathrm{t}$, respectively from $\mathrm{N}_{3}(150 \mathrm{~kg} \mathrm{~N} / \mathrm{ha})$ which was statistically similar (6.58 and $7.0 \mathrm{t}$ at 40 and 50 DAT respectively) with $\mathrm{N}_{2}(100 \mathrm{~kg}$ $\mathrm{N} / \mathrm{ha})$. On the other hand, the lowest yield/ha $(3.0,4.43,5.31$ and $5.9 \mathrm{t}$ at $30,40,50$ and 60 DAT respectively) was recorded from $\mathrm{N}_{0}(0 \mathrm{~kg} \mathrm{~N} / \mathrm{ha})$. It was revealed that with increase of nitrogen maximizes lettuce yield because of increased nitrogen helps plant for higher vegetative growth. The results obtained earlier by Rincon $e t$ al. (1998), Tittonellet al. (2003), Boroujerdnia and Ansari (2007) and MahmoudiKliber (2005) was similar with the present study. Yield/ha of lettuce was statistically significant in terms of different plant spacing at different growth stages (Table 7). At 30, 40, 50 and $60 \mathrm{DAT}$, the maximum yield/ha $(4.98,6.17,7.03$ and $7.66 \mathrm{t}$ respectively) was obtained from $S_{2}(40 \mathrm{~cm} \times 25 \mathrm{~cm})$. On the other hand, the lowest yield/ha $(4.19,5.76,6.35$ and $6.96 \mathrm{t}$ at 30, 40, 50 and 60 DAT respectively) was recorded from $S_{1}(40 \mathrm{~cm} \times 25 \mathrm{~cm})$. It was revealed that with the increases of spacing individual weight per plant increase. So, in spite of less population, total yield/ha may higher due to higher individual plant weight and optimum spacing ensure the highest yield with maximum vegetative growth. Similar result was also tested by Sharma et al. (2001). Significant variation was examined due to interaction effect of different levels of nitrogen and plant spacing in terms of yield/ha at different growth stages of lettuce crop (Table 7). Results showed that the highest yield/ha were 6.44, 7.41, 8.31 and 9.15 t at 30, 40,50 and 60 DAT respectively from $\mathrm{N}_{3} \mathrm{~S}_{2}$. The lowest yield/ha $(2.84,3.89,4.75$ and $5.34 \mathrm{t}$ at 30, 40, 50 and 60 DAT respectively) was recorded from $\mathrm{N}_{0} \mathrm{~S}_{1}$ which was statistically similar with $\mathrm{N}_{0} \mathrm{~S}_{2}$ at 30 DAT. It was revealed that optimum level of nitrogen and plant spacing ensured maximum vegetative growth and the allocation of optimum number of plants that leads to produce the highest yield/ha. 


\section{Table 7}

\subsection{Total yield}

Different levels of nitrogen application influenced total yield of lettuce significantly (Figure 1). It was observed that the highest yield (29.99 t/ha) was obtained from $\mathrm{N}_{3}(150 \mathrm{~kg} \mathrm{~N} / \mathrm{ha})$ where the lowest yield $(18.65$ $\mathrm{t} / \mathrm{ha}$ ) was recorded from $\mathrm{N}_{0}(0 \mathrm{~kg} \mathrm{~N} / \mathrm{ha})$. It was remarked that higher yield was achieved with higher doses of nitrogen due helping plants for higher vegetative growth. The results obtained earlier by Rincon et al. (1998), Tittonellet al. (2003), Boroujerdnia and Ansari (2007) and MahmoudiKliber (2005) was similar with the present study.

\section{Figure 1}

Total yield of lettuce was significantly influenced by different plant spacing (Figure 2). Results indicated that the maximum yield $(25.83 \mathrm{t} / \mathrm{ha})$ was obtained from $\mathrm{S}_{2}(40 \mathrm{~cm} \times 25 \mathrm{~cm})$. On the other hand, the lowest yield $(23 \mathrm{t} / \mathrm{ha})$ was recorded from $S_{1}(40 \mathrm{~cm} \times 20 \mathrm{~cm})$. It was said that higher spacing showed higher yield till to a certain level because of higher population is ensured with lower spacing and higher spacing provide more nutrients and less competition of nutrition for vegetative growth. Similar result was also tested by Sharma et al. (2001).

\section{Figure 2}

Significant variation was examined due to interaction effect of different levels of nitrogen and plant spacing in terms of total yield of lettuce crop (Table 8). Results showed that the highest yield (31.31 t/ha) was obtained from $\mathrm{N}_{3} \mathrm{~S}_{2}$ where the lowest (16.79 t/ha) was from $\mathrm{N}_{0} \mathrm{~S}_{1}$. It was stated that optimum level of nitrogen and plant spacing ensured maximum vegetative growth and ultimate result is to produce the highest yield. Similar result was also achieved by Tittonellet al. (2001).

\subsection{Benefit cost ratio (BCR)}

The combination of nitrogen fertilizer and plant spacing showed different benefit cost ratio in different treatment combinations (Table 8). The highest benefit cost ratio (BCR) (3.887) was performed from $\mathrm{N}_{3} \mathrm{~S}_{2}$ and the second BCR (3.67) was estimated from $\mathrm{N}_{3} \mathrm{~S}_{1}$. The lowest benefit cost ratio (2.10) was obtained from $\mathrm{N}_{0} \mathrm{~S}_{1}$. From economic point of view, it is apparent from the above results that $\mathrm{N}_{3} \mathrm{~S}_{2}$ was the more profitable than rest of the treatment combinations for lettuce crop. Under the present study, the ultimate goal was to achieve highest return with lettuce cultivation applying different treatment combinations and from this point of view the highest net return Benefit Cost Ratio (3.88) were achieved from $\mathrm{N}_{3} \mathrm{~S}_{2}$ where the lowest Benefit Cost Ratio (2.1) were from $\mathrm{N}_{0} \mathrm{~S}_{1}$. From economic point of view, it is apparent from the above results that $\mathrm{N}_{3} \mathrm{~S}_{2}$ was the most profitable than rest of the treatment combinations for lettuce cultivation.

\section{Table 8}

\section{References}

[1] Bansal, G. L., Rana, M. C. and Upadhyay, R. G. 1995. Response of grain amaranth (Amaranthus hypochondriacus) to plant density. Indian Journal of Agricultural Science, 65 (11): 818-820.

[2] Boroujerdnia, M. and Ansari, N. A. 2007. Effect of Different Levels of Nitrogen Fertilizer and Cultivars on Growth, Yield and Yield Components of Romaine Lettuce (Lactuca sativa L.). Department of Horticultural, Faculty of Agriculture, ShahidChamran University, Ahwaz, Iran. Middle Eastern and Russian Journal of Plant Science and Biotechnology, 1(2): 47-53.

[3] Gomez, K. H. and Gomez, A. A. 1984. Statistical Procedures for Agricultural Research. Second Edn. Wiley- Inter Science publication, JohnWiley and Sons, New York. p. 680.

[4] Mahmoudi, K.F.2005. Effects of rates and sources nitrogen fertilizer on nitrate accumulation and yield of lettuce. MSc Thesis, Department of Soil Science, Science and Research Branch, Islamic Azad University, Tehran, Iran, 78 pp (in Farsi)

[5] Moniruzzaman, M. 2006. Effects of plant spacing and mulching on yield and profitability of lettuce (Lactuca sativa L.). Journal of Agriculture and Rural Development,4(1/2): 107-111.

[6] Rincon, L., Pellicer, C., Saez, J.1998. Effect of different nitrogen application rates on yield and nitrate concentration in lettuce crops. Agrochemia42: 304-312.

[7] Sharma,-D-K., Chaudhary,-D-R., Pandey,-D-P. 2001. Growth and yield of lettuce cv. Alamo-1 as influenced by dates of planting and plant density. Varanasi, India: Indian Society of Vegetable Science. Vegetable-Science, 28(1): 38-39.

[8] Sodkowski, P. and Rekowska, E. 2003. The effect of covering and cultivation methods on crisp lettuce yields. Folia Horticulturae, 15(1): 19-23.

[9] Steingrobe, T. and Schenk, D. (1994). Effect of date of transplanting and plant spacing on seed yield and yield characters in lettuce (Lactuca sativacv. Great lakes). Kamataka Journal of Agricultural Science, 5 (4): 357-361.

[10] Squire, G.R., Ong, C.K., Monteith, J.L.1987. Crop growth in semi-arid environment. In: Proceedings of 7th International Workshop, 7-11 April, 1986, International Crops Research Institute for Semi-Arid Tropics, Patancheru, Hyderabad, pp 219-231.

[11] Tehrani, M. and Malakouti, M.J.1997. Recommendation of nitrogen fertilizer according to soil nitrate. First of national congregation decreasing poison consumption and best utilization of chemical fertilizers, Ministry of agricultural, Karaj, Iran, 182 pp (in Farsi)

[12] Tittonell, P.A., de Grazia, J. and Chiesa, A.2003. Nitrate and dry water concentration in a leafy lettuce (Lactuca sativa L.) cultivar as affected by $\mathrm{N}$ fertilization and plant population. AgriculturaTropica and Subtropica36: 82-87. 
Table 1: Effect of nitrogen and plant spacing on plant height at different growth stages of lettuce crop

\begin{tabular}{|c|c|c|c|c|}
\hline \multirow[t]{2}{*}{ Treatment } & \multicolumn{4}{|c|}{ Plant height $(\mathrm{cm})$} \\
\hline & $30 \mathrm{DAT}$ & $40 \mathrm{DAT}$ & 50 DAT & $60 \mathrm{DAT}$ \\
\hline \multicolumn{5}{|c|}{ Main effect of nitrogen } \\
\hline $\mathrm{N}_{0}$ & $10.36 \mathrm{c}$ & $13.79 \mathrm{c}$ & $18.42 \mathrm{c}$ & $21.98 \mathrm{~d}$ \\
\hline $\mathrm{N}_{1}$ & $16.46 \mathrm{~b}$ & $21.05 \mathrm{~b}$ & $25.59 \mathrm{~b}$ & $28.77 \mathrm{c}$ \\
\hline $\mathrm{N}_{2}$ & $16.33 \mathrm{~b}$ & $21.30 \mathrm{ab}$ & $25.23 \mathrm{~b}$ & $29.07 \mathrm{~b}$ \\
\hline $\mathrm{N}_{3}$ & $16.94 \mathrm{a}$ & $21.85 \mathrm{a}$ & $26.36 \mathrm{a}$ & $30.00 \mathrm{a}$ \\
\hline \multicolumn{5}{|c|}{ Main effect of spacing } \\
\hline $\mathrm{S}_{1}$ & $16.73 \mathrm{a}$ & $22.20 \mathrm{a}$ & $26.55 \mathrm{a}$ & $30.46 \mathrm{a}$ \\
\hline $\mathrm{S}_{2}$ & $15.05 \mathrm{~b}$ & $19.58 \mathrm{~b}$ & $24.15 \mathrm{~b}$ & $27.70 \mathrm{~b}$ \\
\hline $\mathrm{S}_{3}$ & $13.30 \mathrm{c}$ & $16.71 \mathrm{c}$ & $21.00 \mathrm{c}$ & $24.21 \mathrm{c}$ \\
\hline \multicolumn{5}{|c|}{ Interaction effect of nitrogen and spacing } \\
\hline $\mathrm{N}_{0} \mathrm{~S}_{1}$ & $11.11 \mathrm{~h}$ & $15.89 \mathrm{~g}$ & $19.11 \mathrm{gh}$ & $23.11 \mathrm{hi}$ \\
\hline $\mathrm{N}_{0} \mathrm{~S}_{2}$ & $10.26 \mathrm{i}$ & $13.59 \mathrm{~h}$ & $18.61 \mathrm{hi}$ & $22.71 \mathrm{i}$ \\
\hline $\mathrm{N}_{0} \mathrm{~S}_{3}$ & $9.71 \mathrm{i}$ & $11.89 \mathrm{i}$ & $17.54 \mathrm{i}$ & $20.11 \mathrm{j}$ \\
\hline $\mathrm{N}_{1} \mathrm{~S}_{1}$ & $17.61 \mathrm{bc}$ & $22.91 \mathrm{bc}$ & $27.61 \mathrm{~b}$ & $31.44 \mathrm{bc}$ \\
\hline $\mathrm{N}_{1} \mathrm{~S}_{2}$ & $16.12 \mathrm{de}$ & $20.69 \mathrm{de}$ & $25.04 \mathrm{de}$ & $27.99 \mathrm{e}$ \\
\hline $\mathrm{N}_{1} \mathrm{~S}_{3}$ & $15.66 \mathrm{e}$ & $19.55 \mathrm{e}$ & $24.11 \mathrm{e}$ & $26.89 \mathrm{ef}$ \\
\hline $\mathrm{N}_{2} \mathrm{~S}_{1}$ & $18.10 \mathrm{~b}$ & $23.80 \mathrm{~b}$ & $27.59 \mathrm{~b}$ & $32.24 \mathrm{~b}$ \\
\hline $\mathrm{N}_{2} \mathrm{~S}_{2}$ & $16.59 \mathrm{~d}$ & $21.79 \mathrm{~cd}$ & $25.96 \mathrm{~cd}$ & $29.60 \mathrm{~d}$ \\
\hline $\mathrm{N}_{2} \mathrm{~S}_{3}$ & $14.31 \mathrm{f}$ & $18.31 \mathrm{f}$ & $22.16 \mathrm{f}$ & $25.39 \mathrm{fg}$ \\
\hline $\mathrm{N}_{3} \mathrm{~S}_{1}$ & $20.09 \mathrm{a}$ & $26.21 \mathrm{a}$ & $31.89 \mathrm{a}$ & $35.05 \mathrm{a}$ \\
\hline $\mathrm{N}_{3} \mathrm{~S}_{2}$ & $17.21 \mathrm{c}$ & $22.24 \mathrm{c}$ & $27.00 \mathrm{bc}$ & $30.51 \mathrm{~cd}$ \\
\hline $\mathrm{N}_{3} \mathrm{~S}_{3}$ & $13.51 \mathrm{~g}$ & $17.10 \mathrm{fg}$ & $20.20 \mathrm{~g}$ & $24.44 \mathrm{gh}$ \\
\hline $\mathrm{CV}(\%)$ & 7.46 & 8.93 & 6.44 & 7.81 \\
\hline
\end{tabular}

In a column, means having similar letter(s) are statistically similar and those having dissimilar letter(s) differ significantly as per 0.05 level of probability

Table 2: Effect of nitrogen and plant spacing on number of leaves/plant at different growth stages of lettuce crop

\begin{tabular}{|c|c|c|c|c|}
\hline \multirow[t]{2}{*}{ Treatment } & \multicolumn{4}{|c|}{ Number of leaves/plant } \\
\hline & $30 \mathrm{DAT}$ & $40 \mathrm{DAT}$ & 50 DAT & $60 \mathrm{DAT}$ \\
\hline \multicolumn{5}{|c|}{ Main effect of nitrogen } \\
\hline $\mathrm{N}_{0}$ & $12.65 \mathrm{~d}$ & $17.23 \mathrm{~d}$ & $22.70 \mathrm{~d}$ & $21.45 \mathrm{c}$ \\
\hline $\mathrm{N}_{1}$ & $15.46 \mathrm{c}$ & $22.26 \mathrm{c}$ & $26.10 \mathrm{c}$ & $24.32 \mathrm{~b}$ \\
\hline $\mathrm{N}_{2}$ & $16.44 \mathrm{~b}$ & $23.60 \mathrm{~b}$ & $27.33 \mathrm{~b}$ & $25.34 \mathrm{~b}$ \\
\hline $\mathrm{N}_{3}$ & $17.45 \mathrm{a}$ & $24.85 \mathrm{a}$ & $29.25 \mathrm{a}$ & $27.20 \mathrm{a}$ \\
\hline $\mathrm{S}_{2}$ & $16.37 \mathrm{a}$ & $23.14 \mathrm{a}$ & $27.39 \mathrm{a}$ & $25.60 \mathrm{a}$ \\
\hline $\mathrm{S}_{3}$ & $16.10 \mathrm{a}$ & $23.13 \mathrm{a}$ & $27.33 \mathrm{a}$ & $25.45 \mathrm{a}$ \\
\hline \multicolumn{5}{|c|}{ Interaction effect of nitrogen and spacing } \\
\hline $\mathrm{N}_{0} \mathrm{~S}_{1}$ & $11.54 \mathrm{~g}$ & $15.44 \mathrm{i}$ & $21.34 \mathrm{j}$ & $20.51 \mathrm{~h}$ \\
\hline $\mathrm{N}_{0} \mathrm{~S}_{2}$ & $13.00 \mathrm{f}$ & $17.81 \mathrm{~h}$ & $23.04 \mathrm{i}$ & $21.70 \mathrm{gh}$ \\
\hline $\mathrm{N}_{2} \mathrm{~S}_{1}$ & $14.89 \mathrm{~cd}$ & $21.24 \mathrm{f}$ & $25.15 \mathrm{fg}$ & $23.11 \mathrm{fg}$ \\
\hline $\mathrm{N}_{2} \mathrm{~S}_{2}$ & $16.46 \mathrm{~b}$ & $24.60 \mathrm{bc}$ & $28.14 \mathrm{~cd}$ & $26.20 \mathrm{~cd}$ \\
\hline $\mathrm{N}_{2} \mathrm{~S}_{3}$ & $17.99 \mathrm{a}$ & $24.96 \mathrm{bc}$ & $28.70 \mathrm{bc}$ & $26.71 \mathrm{bc}$ \\
\hline $\mathrm{N}_{3} \mathrm{~S}_{1}$ & $15.14 \mathrm{~b}-\mathrm{d}$ & $22.11 \mathrm{ef}$ & $26.11 \mathrm{ef}$ & 24.09 ef \\
\hline $\mathrm{N}_{3} \mathrm{~S}_{2}$ & $19.16 \mathrm{a}$ & $27.10 \mathrm{a}$ & $31.77 \mathrm{a}$ & $29.71 \mathrm{a}$ \\
\hline $\mathrm{N}_{3} \mathrm{~S}_{3}$ & $18.04 \mathrm{a}$ & $25.34 \mathrm{~b}$ & $29.87 \mathrm{~b}$ & $27.80 \mathrm{~b}$ \\
\hline $\mathrm{CV}(\%)$ & 5.48 & 7.66 & 8.14 & 7.24 \\
\hline
\end{tabular}

In a column, means having similar letter(s) are statistically similar and those having dissimilar letter(s) differ significantly as per 0.05 level of probability 
Table 3: Effect of nitrogen and plant spacing on leaf length at different growth stages of lettuce crop

\begin{tabular}{|c|c|c|c|c|}
\hline \multirow[t]{2}{*}{ Treatment } & \multicolumn{4}{|c|}{ Leaf length $(\mathrm{cm})$} \\
\hline & $30 \mathrm{DAT}$ & 40 DAT & $50 \mathrm{DAT}$ & $60 \mathrm{DAT}$ \\
\hline \multicolumn{5}{|c|}{ Main effect of nitrogen } \\
\hline $\mathrm{N}_{0}$ & $9.43 \mathrm{~d}$ & $10.63 \mathrm{~d}$ & $16.76 \mathrm{~d}$ & $17.73 \mathrm{~d}$ \\
\hline $\mathrm{N}_{1}$ & $11.68 \mathrm{c}$ & $15.32 \mathrm{c}$ & $20.33 \mathrm{c}$ & $22.95 \mathrm{c}$ \\
\hline $\mathrm{N}_{2}$ & $12.38 \mathrm{~b}$ & $16.60 \mathrm{~b}$ & $21.33 \mathrm{~b}$ & $24.23 \mathrm{~b}$ \\
\hline $\mathrm{N}_{3}$ & $13.09 \mathrm{a}$ & $18.03 \mathrm{a}$ & $22.41 \mathrm{a}$ & $25.28 \mathrm{a}$ \\
\hline \multicolumn{5}{|c|}{ Main effect of spacing } \\
\hline $\mathrm{S}_{1}$ & $10.51 \mathrm{~b}$ & $12.88 \mathrm{~b}$ & $18.64 \mathrm{~b}$ & $20.66 \mathrm{~b}$ \\
\hline $\mathrm{S}_{2}$ & $11.99 \mathrm{a}$ & $16.10 \mathrm{a}$ & $20.87 \mathrm{a}$ & $23.32 \mathrm{a}$ \\
\hline $\mathrm{S}_{3}$ & $12.44 \mathrm{a}$ & $16.44 \mathrm{a}$ & $21.13 \mathrm{a}$ & $23.67 \mathrm{a}$ \\
\hline \multicolumn{5}{|c|}{ Interaction effect of nitrogen and spacing } \\
\hline $\mathrm{N}_{0} \mathrm{~S}_{1}$ & $8.94 \mathrm{~g}$ & $9.09 \mathrm{i}$ & $15.19 \mathrm{j}$ & $16.09 \mathrm{i}$ \\
\hline $\mathrm{N}_{0} \mathrm{~S}_{2}$ & $9.15 \mathrm{~g}$ & $10.89 \mathrm{~h}$ & $17.10 \mathrm{i}$ & $18.00 \mathrm{~h}$ \\
\hline $\mathrm{N}_{0} \mathrm{~S}_{3}$ & $10.20 \mathrm{f}$ & $11.90 \mathrm{gh}$ & $18.00 \mathrm{~h}$ & $19.11 \mathrm{~g}$ \\
\hline $\mathrm{N}_{1} \mathrm{~S}_{1}$ & $10.64 \mathrm{f}$ & $13.15 \mathrm{fg}$ & $18.96 \mathrm{~g}$ & $21.26 \mathrm{f}$ \\
\hline $\mathrm{N}_{1} \mathrm{~S}_{2}$ & $12.00 \mathrm{de}$ & $16.10 \mathrm{~cd}$ & $20.90 \mathrm{de}$ & $23.39 \mathrm{de}$ \\
\hline $\mathrm{N}_{1} \mathrm{~S}_{3}$ & $12.40 \mathrm{~cd}$ & $16.71 \mathrm{~cd}$ & $21.14 \mathrm{de}$ & $24.21 \mathrm{~cd}$ \\
\hline $\mathrm{N}_{2} \mathrm{~S}_{1}$ & $10.80 \mathrm{f}$ & $14.00 \mathrm{ef}$ & $19.89 \mathrm{f}$ & $22.40 \mathrm{e}$ \\
\hline $\mathrm{N}_{2} \mathrm{~S}_{2}$ & $12.90 \mathrm{bc}$ & $17.54 \mathrm{bc}$ & $21.70 \mathrm{~cd}$ & $24.90 \mathrm{bc}$ \\
\hline $\mathrm{N}_{2} \mathrm{~S}_{3}$ & $13.44 \mathrm{ab}$ & $18.26 \mathrm{~b}$ & $22.42 \mathrm{bc}$ & $25.40 \mathrm{~b}$ \\
\hline $\mathrm{N}_{3} \mathrm{~S}_{1}$ & $11.66 \mathrm{e}$ & $15.29 \mathrm{de}$ & $20.51 \mathrm{ef}$ & $22.89 \mathrm{e}$ \\
\hline $\mathrm{N}_{3} \mathrm{~S}_{2}$ & $13.89 \mathrm{a}$ & $19.89 \mathrm{a}$ & $23.79 \mathrm{a}$ & $27.00 \mathrm{a}$ \\
\hline $\mathrm{N}_{3} \mathrm{~S}_{3}$ & $13.71 \mathrm{a}$ & $18.90 \mathrm{ab}$ & $22.94 \mathrm{~b}$ & $25.96 \mathrm{ab}$ \\
\hline $\mathrm{CV}(\%)$ & 6.57 & 6.28 & 7.22 & 8.36 \\
\hline
\end{tabular}

In a column, means having similar letter(s) are statistically similar and those having dissimilar letter(s) differ significantly as per 0.05 level of probability

Table 4: Effect of nitrogen and plant spacing on leaf breadth at different growth stages of lettuce crop

\begin{tabular}{|c|c|c|c|c|}
\hline \multirow[t]{2}{*}{ Treatment } & \multicolumn{4}{|c|}{ Leaf breadth $(\mathrm{cm})$} \\
\hline & $30 \mathrm{DAT}$ & $40 \mathrm{DAT}$ & $50 \mathrm{DAT}$ & $60 \mathrm{DAT}$ \\
\hline \multicolumn{5}{|c|}{ Main effect of nitrogen } \\
\hline $\mathrm{N}_{0}$ & $6.70 \mathrm{~d}$ & $9.63 \mathrm{~d}$ & $12.72 \mathrm{~d}$ & $15.73 \mathrm{~d}$ \\
\hline $\mathrm{N}_{1}$ & $9.78 \mathrm{c}$ & $14.04 \mathrm{c}$ & $19.66 \mathrm{c}$ & $23.18 \mathrm{c}$ \\
\hline $\mathrm{N}_{2}$ & $10.33 \mathrm{~b}$ & $14.28 \mathrm{~b}$ & $21.66 \mathrm{~b}$ & $25.01 \mathrm{~b}$ \\
\hline $\mathrm{N}_{3}$ & $11.33 \mathrm{a}$ & $15.58 \mathrm{a}$ & $23.26 \mathrm{a}$ & $26.57 \mathrm{a}$ \\
\hline \multicolumn{5}{|c|}{ Main effect of spacing } \\
\hline $\mathrm{S}_{1}$ & $8.09 \mathrm{c}$ & $11.54 \mathrm{c}$ & $16.27 \mathrm{c}$ & $19.20 \mathrm{c}$ \\
\hline $\mathrm{S}_{2}$ & $10.07 \mathrm{~b}$ & $13.99 \mathrm{~b}$ & $20.53 \mathrm{~b}$ & $23.99 \mathrm{~b}$ \\
\hline $\mathrm{S}_{3}$ & $10.45 \mathrm{a}$ & $14.62 \mathrm{a}$ & $21.18 \mathrm{a}$ & $24.69 \mathrm{a}$ \\
\hline \multicolumn{5}{|c|}{ Interaction effect of nitrogen and spacing } \\
\hline $\mathrm{N}_{0} \mathrm{~S}_{1}$ & $6.10 \mathrm{~g}$ & $8.04 \mathrm{i}$ & $11.49 \mathrm{i}$ & $14.25 \mathrm{i}$ \\
\hline $\mathrm{N}_{0} \mathrm{~S}_{2}$ & $6.69 \mathrm{fg}$ & $10.00 \mathrm{~h}$ & $12.90 \mathrm{~h}$ & $16.01 \mathrm{~h}$ \\
\hline $\mathrm{N}_{0} \mathrm{~S}_{3}$ & $7.31 \mathrm{f}$ & $10.86 \mathrm{~g}$ & $13.79 \mathrm{~h}$ & $16.94 \mathrm{~h}$ \\
\hline $\mathrm{N}_{1} \mathrm{~S}_{1}$ & $8.14 \mathrm{e}$ & $13.56 \mathrm{de}$ & $15.80 \mathrm{~g}$ & $18.99 \mathrm{~g}$ \\
\hline $\mathrm{N}_{1} \mathrm{~S}_{2}$ & $10.39 \mathrm{c}$ & $13.80 \mathrm{~d}$ & $21.00 \mathrm{de}$ & $24.66 \mathrm{~d}$ \\
\hline $\mathrm{N}_{1} \mathrm{~S}_{3}$ & $10.80 \mathrm{bc}$ & $14.75 \mathrm{c}$ & $22.19 \mathrm{~cd}$ & $25.90 \mathrm{~cd}$ \\
\hline $\mathrm{N}_{2} \mathrm{~S}_{1}$ & $8.70 \mathrm{de}$ & $11.70 \mathrm{f}$ & $17.91 \mathrm{f}$ & $20.86 \mathrm{f}$ \\
\hline $\mathrm{N}_{2} \mathrm{~S}_{2}$ & $11.01 \mathrm{bc}$ & $15.24 \mathrm{bc}$ & $23.34 \mathrm{bc}$ & $26.89 \mathrm{bc}$ \\
\hline $\mathrm{N}_{2} \mathrm{~S}_{3}$ & $11.29 \mathrm{~b}$ & $15.89 \mathrm{~b}$ & $23.74 \mathrm{ab}$ & $27.30 \mathrm{ab}$ \\
\hline $\mathrm{N}_{3} \mathrm{~S}_{1}$ & $9.40 \mathrm{~d}$ & $12.84 \mathrm{e}$ & $19.89 \mathrm{e}$ & $22.70 \mathrm{e}$ \\
\hline $\mathrm{N}_{3} \mathrm{~S}_{2}$ & $12.19 \mathrm{a}$ & $16.90 \mathrm{a}$ & $24.89 \mathrm{a}$ & $28.40 \mathrm{a}$ \\
\hline $\mathrm{N}_{3} \mathrm{~S}_{3}$ & $12.40 \mathrm{a}$ & $16.99 \mathrm{a}$ & $25.01 \mathrm{a}$ & $28.61 \mathrm{a}$ \\
\hline $\mathrm{CV}(\%)$ & 8.33 & 7.49 & 6.87 & 9.24 \\
\hline
\end{tabular}

In a column, means having similar letter(s) are statistically similar and those having dissimilar letter(s) differ significantly as per 0.05 level of probability 
Growth And Yield Of Lettuce (Lactuca Sativa L.) Influenced As Nitrogen Fertilizer And Plant

Table 5: Effect of nitrogen and plant spacing on fresh weight/plant at different growth stages of lettuce crop

\begin{tabular}{|c|c|c|c|c|}
\hline \multirow[t]{2}{*}{ Treatment } & \multicolumn{4}{|c|}{ Fresh weight/plant } \\
\hline & 30 DAT & 40 DAT & $50 \mathrm{DAT}$ & 60 DAT \\
\hline \multicolumn{5}{|c|}{ Main effect of nitrogen } \\
\hline $\mathrm{N}_{0}$ & $45.07 \mathrm{~d}$ & $56.12 \mathrm{~d}$ & $67.73 \mathrm{~d}$ & $75.79 \mathrm{~d}$ \\
\hline $\mathrm{N}_{1}$ & $66.66 \mathrm{c}$ & $78.29 \mathrm{c}$ & $91.77 \mathrm{c}$ & $98.38 \mathrm{c}$ \\
\hline $\mathrm{N}_{2}$ & $77.86 \mathrm{~b}$ & $89.04 \mathrm{~b}$ & $99.58 \mathrm{~b}$ & $108.90 \mathrm{~b}$ \\
\hline $\mathrm{N}_{3}$ & $87.23 \mathrm{a}$ & $102.30 \mathrm{a}$ & $115.30 \mathrm{a}$ & $126.00 \mathrm{a}$ \\
\hline \multicolumn{5}{|c|}{ Main effect of spacing } \\
\hline $\mathrm{S}_{1}$ & $55.06 \mathrm{c}$ & $65.40 \mathrm{c}$ & $75.36 \mathrm{c}$ & $83.01 \mathrm{c}$ \\
\hline $\mathrm{S}_{2}$ & $71.01 \mathrm{~b}$ & $84.34 \mathrm{~b}$ & $96.39 \mathrm{~b}$ & $106.8 \mathrm{~b}$ \\
\hline $\mathrm{S}_{3}$ & $81.55 \mathrm{a}$ & $94.58 \mathrm{a}$ & $109.00 \mathrm{a}$ & $117.00 \mathrm{a}$ \\
\hline \multicolumn{5}{|c|}{ Interaction effect of nitrogen and spacing } \\
\hline $\mathrm{N}_{0} \mathrm{~S}_{1}$ & $36.65 \mathrm{j}$ & $44.69 \mathrm{~h}$ & $54.44 \mathrm{~h}$ & $62.59 \mathrm{~h}$ \\
\hline $\mathrm{N}_{0} \mathrm{~S}_{2}$ & $46.21 \mathrm{i}$ & $59.55 \mathrm{~g}$ & $70.34 \mathrm{~g}$ & $79.49 \mathrm{~g}$ \\
\hline $\mathrm{N}_{0} \mathrm{~S}_{3}$ & $52.36 \mathrm{~h}$ & $64.11 \mathrm{f}$ & 78.39 ef & $85.29 \mathrm{f}$ \\
\hline $\mathrm{N}_{1} \mathrm{~S}_{1}$ & $54.24 \mathrm{~h}$ & $62.54 \mathrm{fg}$ & $74.66 \mathrm{f}$ & $80.11 \mathrm{~g}$ \\
\hline $\mathrm{N}_{1} \mathrm{~S}_{2}$ & $68.46 \mathrm{f}$ & $80.89 \mathrm{~d}$ & $94.43 \mathrm{~d}$ & $103.50 \mathrm{e}$ \\
\hline $\mathrm{N}_{1} \mathrm{~S}_{3}$ & $77.29 \mathrm{e}$ & $91.45 \mathrm{c}$ & $106.2 \mathrm{c}$ & $111.50 \mathrm{~d}$ \\
\hline $\mathrm{N}_{2} \mathrm{~S}_{1}$ & $60.89 \mathrm{~g}$ & $71.99 \mathrm{e}$ & 80.89 e & $88.11 \mathrm{f}$ \\
\hline $\mathrm{N}_{2} \mathrm{~S}_{2}$ & $80.24 \mathrm{~d}$ & $92.49 \mathrm{c}$ & $102.6 \mathrm{c}$ & $112.20 \mathrm{~d}$ \\
\hline $\mathrm{N}_{2} \mathrm{~S}_{3}$ & $92.44 \mathrm{~b}$ & $102.60 \mathrm{~b}$ & $115.3 \mathrm{~b}$ & $126.40 \mathrm{c}$ \\
\hline $\mathrm{N}_{3} \mathrm{~S}_{1}$ & $68.45 \mathrm{f}$ & $82.36 \mathrm{~d}$ & $91.46 \mathrm{~d}$ & $101.20 \mathrm{e}$ \\
\hline $\mathrm{N}_{3} \mathrm{~S}_{2}$ & $89.14 \mathrm{c}$ & $104.40 \mathrm{~b}$ & $118.2 \mathrm{~b}$ & $132.00 \mathrm{~b}$ \\
\hline $\mathrm{N}_{3} \mathrm{~S}_{3}$ & $104.10 \mathrm{a}$ & $120.10 \mathrm{a}$ & $136.2 \mathrm{a}$ & $144.90 \mathrm{a}$ \\
\hline $\mathrm{CV}(\%)$ & 8.88 & 7.98 & 9.42 & 7.66 \\
\hline
\end{tabular}

In a column, means having similar letter(s) are statistically similar and those having dissimilar letter(s) differ significantly as per 0.05 level of probability

Table 6: Effect of nitrogen and plant spacing on dry weight/plant at different growth stages of lettuce crop

\begin{tabular}{|c|c|c|c|c|}
\hline \multirow[t]{2}{*}{ Treatment } & \multicolumn{4}{|c|}{ Dry weight/plant } \\
\hline & 30 DAT & $40 \mathrm{DAT}$ & $50 \mathrm{DAT}$ & $60 \mathrm{DAT}$ \\
\hline \multicolumn{5}{|c|}{ Main effect of nitrogen } \\
\hline $\mathrm{N}_{0}$ & $6.80 \mathrm{~d}$ & $8.23 \mathrm{~d}$ & $9.83 \mathrm{~d}$ & $10.89 \mathrm{~d}$ \\
\hline $\mathrm{N}_{1}$ & $9.74 \mathrm{c}$ & $11.08 \mathrm{c}$ & $13.21 \mathrm{c}$ & $14.16 \mathrm{c}$ \\
\hline $\mathrm{N}_{2}$ & $11.32 \mathrm{~b}$ & $12.80 \mathrm{~b}$ & $14.32 \mathrm{~b}$ & $15.66 \mathrm{~b}$ \\
\hline $\mathrm{N}_{3}$ & $12.46 \mathrm{a}$ & $14.68 \mathrm{a}$ & $16.56 \mathrm{a}$ & $18.05 \mathrm{a}$ \\
\hline \multicolumn{5}{|c|}{ Main effect of spacing } \\
\hline$S_{1}$ & $8.09 \mathrm{c}$ & $9.36 \mathrm{c}$ & $10.84 \mathrm{c}$ & $11.89 \mathrm{c}$ \\
\hline $\mathrm{S}_{2}$ & $10.31 \mathrm{~b}$ & $12.02 \mathrm{~b}$ & $13.93 \mathrm{~b}$ & $15.37 \mathrm{~b}$ \\
\hline$S_{3}$ & $11.83 \mathrm{a}$ & $13.72 \mathrm{a}$ & $15.67 \mathrm{a}$ & $16.81 \mathrm{a}$ \\
\hline \multicolumn{5}{|c|}{ Interaction effect of nitrogen and spacing } \\
\hline $\mathrm{N}_{0} \mathrm{~S}_{1}$ & $5.84 \mathrm{~g}$ & $6.85 \mathrm{~g}$ & $7.76 \mathrm{~g}$ & $8.99 \mathrm{f}$ \\
\hline $\mathrm{N}_{0} \mathrm{~S}_{2}$ & $6.86 \mathrm{fg}$ & $8.19 \mathrm{fg}$ & $10.46 \mathrm{f}$ & $11.39 \mathrm{e}$ \\
\hline $\mathrm{N}_{0} \mathrm{~S}_{3}$ & 7.69 ef & 9.66 ef & $11.29 \mathrm{f}$ & $12.29 \mathrm{e}$ \\
\hline $\mathrm{N}_{1} \mathrm{~S}_{1}$ & 7.95 ef & $8.40 \mathrm{fg}$ & $10.79 \mathrm{f}$ & $11.65 \mathrm{e}$ \\
\hline $\mathrm{N}_{1} \mathrm{~S}_{2}$ & $9.89 \mathrm{~d}$ & $11.67 \mathrm{~cd}$ & $13.56 \mathrm{~d}$ & $14.88 \mathrm{~cd}$ \\
\hline $\mathrm{N}_{1} \mathrm{~S}_{3}$ & $11.39 \mathrm{c}$ & $13.19 \mathrm{bc}$ & $15.29 \mathrm{bc}$ & $15.94 \mathrm{~cd}$ \\
\hline $\mathrm{N}_{2} \mathrm{~S}_{1}$ & $8.88 \mathrm{de}$ & $10.36 \mathrm{de}$ & 11.64 ef & $12.46 \mathrm{e}$ \\
\hline $\mathrm{N}_{2} \mathrm{~S}_{2}$ & $11.75 \mathrm{c}$ & $13.29 \mathrm{bc}$ & $14.78 \mathrm{~cd}$ & $16.31 \mathrm{c}$ \\
\hline $\mathrm{N}_{2} \mathrm{~S}_{3}$ & $13.31 \mathrm{~b}$ & $14.74 \mathrm{~b}$ & $16.54 \mathrm{~b}$ & $18.20 \mathrm{~b}$ \\
\hline $\mathrm{N}_{3} \mathrm{~S}_{1}$ & $9.69 \mathrm{~d}$ & $11.84 \mathrm{~cd}$ & $13.19 \mathrm{de}$ & $14.45 \mathrm{~d}$ \\
\hline $\mathrm{N}_{3} \mathrm{~S}_{2}$ & $12.75 \mathrm{bc}$ & $14.93 \mathrm{~b}$ & $16.94 \mathrm{~b}$ & $18.90 \mathrm{~b}$ \\
\hline $\mathrm{N}_{3} \mathrm{~S}_{3}$ & $14.94 \mathrm{a}$ & $17.29 \mathrm{a}$ & $19.56 \mathrm{a}$ & $20.80 \mathrm{a}$ \\
\hline $\mathrm{CV}(\%)$ & 4.68 & 7.84 & 5.23 & 6.11 \\
\hline
\end{tabular}

In a column, means having similar letter(s) are statistically similar and those having dissimilar letter(s) differ significantly as per 0.05 level of probability 
Growth And Yield Of Lettuce (Lactuca Sativa L.) Influenced As Nitrogen Fertilizer And Plant

Table 7: Effect of nitrogen and plant spacing on yield (t/ha) at different growth stages of lettuce crop

\begin{tabular}{|c|c|c|c|c|}
\hline \multirow[t]{2}{*}{ Treatment } & \multicolumn{4}{|c|}{ Yield (t/ha) } \\
\hline & $30 \mathrm{DAT}$ & $40 \mathrm{DAT}$ & $50 \mathrm{DAT}$ & $60 \mathrm{DAT}$ \\
\hline \multicolumn{5}{|c|}{ Main effect of nitrogen } \\
\hline $\mathrm{N}_{0}$ & $3.01 \mathrm{c}$ & $4.43 \mathrm{c}$ & $5.31 \mathrm{c}$ & $5.90 \mathrm{c}$ \\
\hline $\mathrm{N}_{1}$ & $4.11 \mathrm{~b}$ & $5.62 \mathrm{~b}$ & $6.39 \mathrm{~b}$ & $6.98 \mathrm{~b}$ \\
\hline $\mathrm{N}_{2}$ & $5.00 \mathrm{~b}$ & $6.58 \mathrm{ab}$ & $7.08 \mathrm{ab}$ & $7.63 \mathrm{~b}$ \\
\hline $\mathrm{N}_{3}$ & $6.08 \mathrm{a}$ & $7.15 \mathrm{a}$ & $8.00 \mathrm{a}$ & $8.76 \mathrm{a}$ \\
\hline \multicolumn{5}{|c|}{ Main effect of spacing } \\
\hline $\mathrm{S}_{1}$ & $4.19 \mathrm{~b}$ & $5.76 \mathrm{~b}$ & $6.35 \mathrm{c}$ & $6.96 \mathrm{c}$ \\
\hline $\mathrm{S}_{2}$ & $4.98 \mathrm{a}$ & $6.17 \mathrm{a}$ & $7.03 \mathrm{a}$ & $7.66 \mathrm{a}$ \\
\hline $\mathrm{S}_{3}$ & $4.49 \mathrm{~b}$ & $5.91 \mathrm{ab}$ & $6.71 \mathrm{~b}$ & $7.33 \mathrm{~b}$ \\
\hline \multicolumn{5}{|c|}{ Interaction effect of nitrogen and spacing } \\
\hline $\mathrm{N}_{0} \mathrm{~S}_{1}$ & $2.84 \mathrm{i}$ & $3.89 \mathrm{k}$ & $4.75 \mathrm{~h}$ & $5.34 \mathrm{~h}$ \\
\hline $\mathrm{N}_{0} \mathrm{~S}_{2}$ & $3.01 \mathrm{hi}$ & $4.50 \mathrm{j}$ & $5.46 \mathrm{~g}$ & $6.01 \mathrm{~g}$ \\
\hline $\mathrm{N}_{0} \mathrm{~S}_{3}$ & $3.19 \mathrm{~h}$ & $4.91 \mathrm{i}$ & $5.74 \mathrm{fg}$ & $6.34 \mathrm{fg}$ \\
\hline $\mathrm{N}_{1} \mathrm{~S}_{1}$ & $3.50 \mathrm{~g}$ & $5.21 \mathrm{~h}$ & 5.96 ef & 6.54 ef \\
\hline $\mathrm{N}_{1} \mathrm{~S}_{2}$ & $4.96 \mathrm{~d}$ & $6.16 \mathrm{f}$ & $7.00 \mathrm{~cd}$ & $7.59 \mathrm{~cd}$ \\
\hline $\mathrm{N}_{1} \mathrm{~S}_{3}$ & $3.86 \mathrm{f}$ & $5.50 \mathrm{~g}$ & $6.21 \mathrm{e}$ & $6.81 \mathrm{e}$ \\
\hline $\mathrm{N}_{2} \mathrm{~S}_{1}$ & $4.31 \mathrm{e}$ & $6.79 \mathrm{~cd}$ & $6.75 \mathrm{~d}$ & $7.29 \mathrm{~d}$ \\
\hline $\mathrm{N}_{2} \mathrm{~S}_{2}$ & $5.49 \mathrm{c}$ & $6.59 \mathrm{de}$ & $7.34 \mathrm{c}$ & $7.89 \mathrm{c}$ \\
\hline $\mathrm{N}_{2} \mathrm{~S}_{3}$ & $5.21 \mathrm{~d}$ & 6.35 ef & $7.16 \mathrm{c}$ & $7.71 \mathrm{c}$ \\
\hline $\mathrm{N}_{3} \mathrm{~S}_{1}$ & $6.10 \mathrm{~b}$ & $7.14 \mathrm{~b}$ & $7.96 \mathrm{~b}$ & $8.66 \mathrm{~b}$ \\
\hline $\mathrm{N}_{3} \mathrm{~S}_{2}$ & $6.44 \mathrm{a}$ & $7.41 \mathrm{a}$ & $8.31 \mathrm{a}$ & $9.15 \mathrm{a}$ \\
\hline $\mathrm{N}_{3} \mathrm{~S}_{3}$ & $5.71 \mathrm{c}$ & $6.89 \mathrm{bc}$ & $7.75 \mathrm{~b}$ & $8.46 \mathrm{~b}$ \\
\hline $\mathrm{CV}(\%)$ & 4.53 & 6.57 & 7.28 & 8.44 \\
\hline
\end{tabular}

In a column, means having similar letter(s) are statistically similar and those having dissimilar letter(s) differ significantly as per 0.05 level of probability

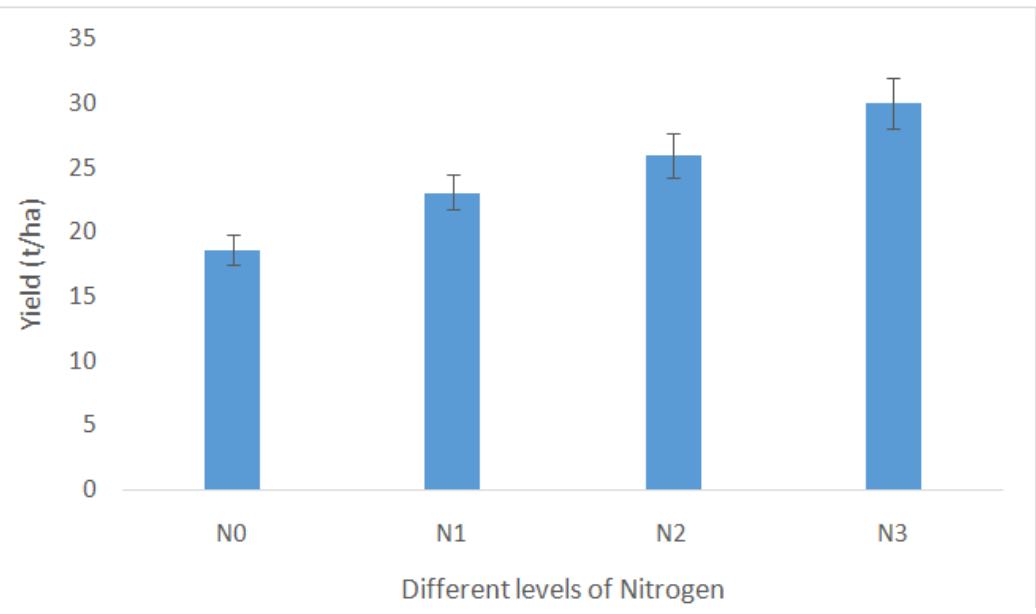

Figure 1: Effect of nitrogen on total yield of lettuce

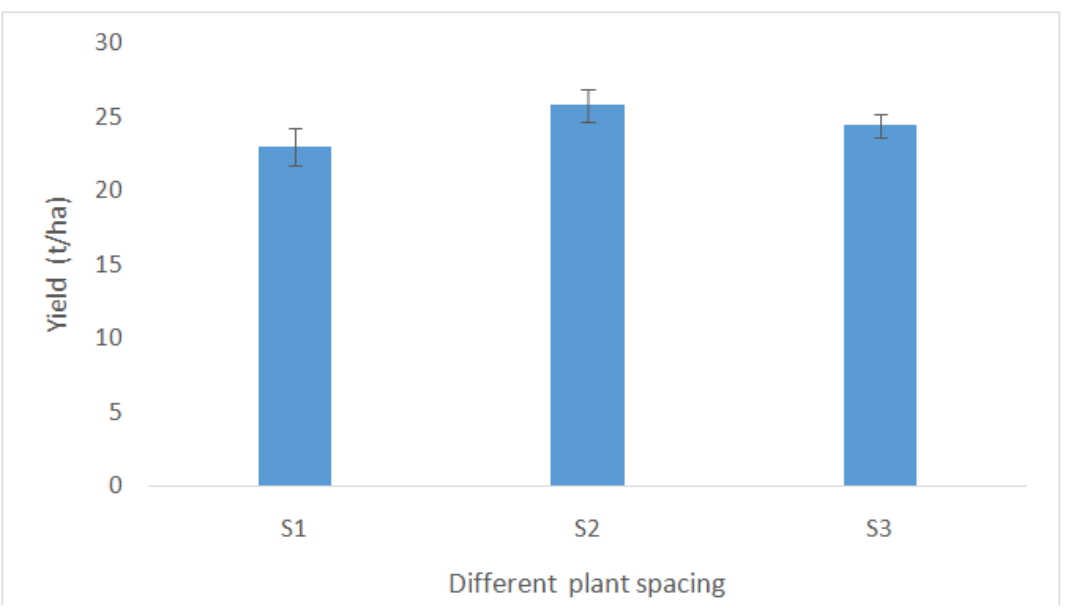

Figure 2: Effect of different plant spacing on total yield of lettuce 
Growth And Yield Of Lettuce (Lactuca Sativa L.) Influenced As Nitrogen Fertilizer And Plant

Table 8: The combined effect of nitrogen and plant spacing on total yield and BCR of lettuce crop

\begin{tabular}{|c|c|c|}
\hline Treatments & Total Yield (t/ha) & Benefit cost ratio (BCR) \\
\hline $\mathrm{N}_{0} \mathrm{~S}_{1}$ & $16.79 \mathrm{j}$ & 2.100 \\
\hline $\mathrm{N}_{0} \mathrm{~S}_{2}$ & $19.00 \mathrm{i}$ & 2.393 \\
\hline $\mathrm{N}_{0} \mathrm{~S}_{3}$ & $20.16 \mathrm{hi}$ & 2.550 \\
\hline $\mathrm{N}_{1} \mathrm{~S}_{1}$ & $21.21 \mathrm{gh}$ & 2.643 \\
\hline $\mathrm{N}_{1} \mathrm{~S}_{2}$ & 3.213 \\
\hline $\mathrm{N}_{1} \mathrm{~S}_{3}$ & $25.71 \mathrm{de}$ & 2.813 \\
\hline $\mathrm{N}_{2} \mathrm{~S}_{1}$ & $22.39 \mathrm{fg}$ & 2.993 \\
\hline $\mathrm{N}_{2} \mathrm{~S}_{2}$ & $24.14 \mathrm{ef}$ & 3.393 \\
\hline $\mathrm{N}_{2} \mathrm{~S}_{3}$ & $27.29 \mathrm{~cd}$ & 3.307 \\
\hline $\mathrm{N}_{3} \mathrm{~S}_{1}$ & $26.44 \mathrm{~d}$ & 3.663 \\
\hline $\mathrm{N}_{3} \mathrm{~S}_{2}$ & $29.86 \mathrm{ab}$ & 3.887 \\
\hline $\mathrm{N}_{3} \mathrm{~S}_{3}$ & $31.31 \mathrm{a}$ & 3.580 \\
\hline $\mathrm{CV}(\%)$ & $28.80 \mathrm{bc}$ & 5.66 \\
\hline
\end{tabular}

In a column, means having similar letter(s) are statistically similar and those having dissimilar letter(s) differ significantly as per 0.05 level of probability 